\title{
Nanoflagellates (mixotrophs, heterotrophs and autotrophs) in the oligotrophic eastern Mediterranean: standing stocks, bacterivory and relationships with bacterial production
}

\author{
Urania Christaki ${ }^{1, *}$, France Van Wambeke ${ }^{2}$, John R. Dolan ${ }^{3}$ \\ ${ }^{1}$ NCMR Aghios Kosmas, GR-16604 Hellinikon, Greece \\ ${ }^{2}$ Microbiologie Marine, CNRS, UPR 223, Campus de Luminy, Case 907, F-13288 Marseille, Cedex 9, France \\ ${ }^{3}$ Marine Microbial Ecology, CNRS ESA 7076, Station Zoologique, F-06234 Villefranche-sur-Mer, Cedex, France
}

\begin{abstract}
The vertical distribution ( 0 to $100 \mathrm{~m})$ and abundance of nanoflagellates were examined in the oligotrophic Aegean Sea (east Mediterranean) in early spring (south basin) and late summer (north and south basins) of 1997 in the framework of the MATER project (Mass Transfer and Ecosystem Response). Different trophic types of nanoflagellates (mixotrophic, heterotrophic, and phototrophic) were identified based on the possession of chloroplasts and the consumption of Fluorescently Labelled Minicells (FLM). Bacterial production (leucine method) was compared with bacterivory estimated from FLM consumption. We found that mixotrophic nanoflagellates played a small role as bacterivores relative to heterotrophic nanoflagellates and total bacterivory roughly balanced bacterial production. In early spring with cool $\left(14.2^{\circ} \mathrm{C}\right)$ well-mixed water columns, flagellate concentrations were lowest, phototrophic flagellates were the dominant group and concentrations varied little with depth. Average concentrations of mixotrophs, heterotrophs and autotrophs were $0.07,0.34$, and $0.64 \times 10^{3}$ cells $\mathrm{ml}^{-1}$, respectively. Bacterial production in the 0 to $100 \mathrm{~m}$ layer averaged about $0.74 \mu \mathrm{g} \mathrm{Cl}^{-1} \mathrm{~d}^{-1}$. Estimated nanoflagellate bacterivory from FLM ingestion accounted for $40 \%$ of bacterial production with mixotrophic nanoflagellates consuming $5 \%$ of bacterial production. In late summer, total nanoflagellate concentrations were higher. Average concentrations of mixotrophs, heterotrophs and autotrophs were $0.09,1.14$, and $0.66 \times 10^{3}$ cells $\mathrm{ml}^{-3}$, respectively, in the southern basin and $0.09,1.1$, and $0.98 \times$ $10^{3}$ cells $\mathrm{ml}^{-1}$, respectively, in the northern basin. In September, bacterial production for both basins roughly balanced estimated nanoflagellate consumption. Similar to the March estimates, mixotrophic nanoflagellates accounted for about $5 \%$ of nanoflagellate bacterivory. In a nutrient enrichment experiment in March, treatments including phosphorus resulted in increased bacterial. production and reductions in identifiable mixotrophs.
\end{abstract}

KEY WORDS: Nanoflagellates Bacteria - Bacterial production - Mixotrophy - MATER project

\section{INTRODUCTION}

In oligotrophic systems, carbon stocks in the form of bacteria are proportionately larger compared to more productive systems (e.g. Gasol et al. 1997). Hence, in an oligotrophic system, bacterivory should represent a substantial carbon flux pathway but the fate of bacterial production is difficult to predict. Commonly, hetero-

•E-mail: urania@erato.fl.ncmr.gr trophic nanoflagellates are recognized as dominating bacterivory although mortality due to viral attack can be important in coastal waters (Fuhrman \& Noble 1995). However, oligotrophic conditions generally correspond to concentrations of bacteria below $1 \times 10^{6}$ cells $\mathrm{ml}^{-1}$, lower than levels often associated with efficient bacterivory by heterotrophic nanoflagellates (Fenchel 1982, Eccleston-Parry \& Leadbeater 1994, Zubkov \& Sleigh 1995) or significant mortality due to viruses (e.g. Steward et al. 1996). Furthermore, in oligotrophic systems, inorganic nutrients can limit both 


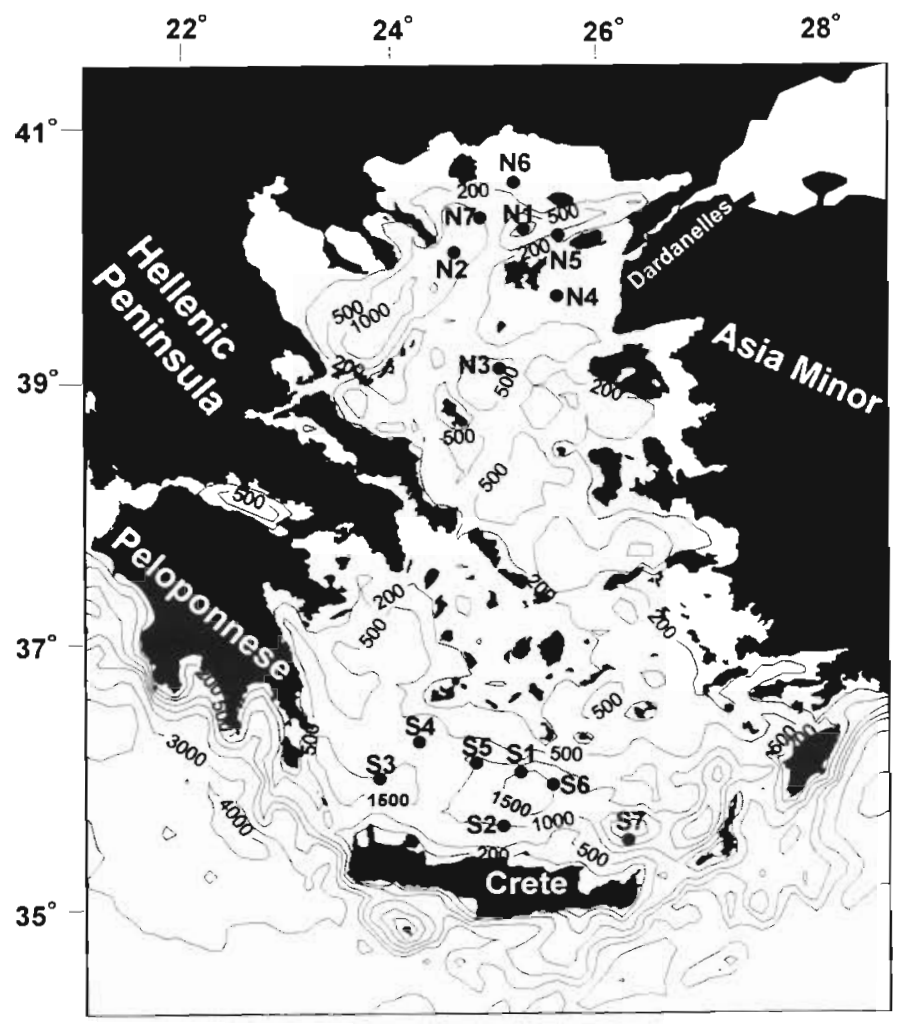

Fig. 1. Station locations in the Aegean Sea

primary and bacterial production, leading to competition between autotrophs and heterotrophs. In such a situation, mixotrophy among chloroplast-containing nanoflagellates may become a dominant trophic strategy, one of 'eating your competitor'--heterotrophic bacteria (Nygaard \& Tobiesen 1993, Riemann et al. 1995. Thingstad et al. 1996). Thus mixotrophy, the combination of photoautotrophic and heterotrophic nutrition in a single individual, is used here in the more restricted sense of the combination photosynthesis and phagotrophy (Riemann et al. 1995).

It seems reasonable to expect that bacterivory from mixotrophic nanoflagellates could be important in oligotrophic systems. Interestingly, at present there is very little data available concerning the abundance and activities of mixotrophic nanoplankton in oligotrophic marine systems. Previous studies have largely concerned brackish water environments (Epstein \& Shians 1992, Havskum \& Riemann 1996, Havskum \& Hansen 1997) while data from coastal waters suggested that phytoflagellates may dominate bacterivory (Hall et al. 1993, Nygaard \& Tobiesen 1993). Data from the oligotrophic Sargasso Sea suggest a small proportion of phytoflagellates ingest bacteria (Arenovski et al. 1995).

The Aegean Sea is a sub-system of the eastern Mediterranean and can be considered oligotrophic in terms of annual averages of standing stocks of chloro-

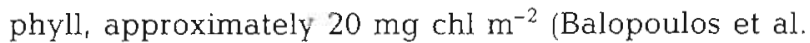
1997 ) or in terms of primary production, approximately $68 \mathrm{mg} \mathrm{C} \mathrm{m} \mathrm{d}^{-2} \mathrm{~d}^{-1}$ (Ignatiades 1998). Cruises in the Aegean were conducted as part of the European project MATER (Mass Transfer and Ecosystem Response). The overall project goal is the collection of data on the dynamics of water masses and the behavior of dissolved and particulate matter (especially carbon) for the eventual construction of a predictive model of the Mediterranean. Aegean stations were sampled when the water column was mixed, in March 1997 in the southern Aegean and in both the north and south Aegean in September 1997, in typical late summer conditions of thermal stratification.

The goal of our study was to examine the relationship between the consumption of heterotrophic bacteria by nanoflagellates and bacterial production, paying particular attention to the role of mixotrophic nanoflagellates. We estimated bacterial consumption by heterotrophic and mixotrophic nanoflagellates using prey analogs and compared it with bacterial production estimated via ${ }^{3} \mathrm{H}$-leucine method. We also examined the role of inorganic nutrients as a factor influencing mixotrophy among nanoflagellates and bacterial production rates in an oligotrophic marine system.

\section{MATERIALS AND METHODS}

Study site, sampling strategy. Both the north and the south Aegean (Fig. 1) can be characterized as oligotrophic but in the north, due to input from the Black Sea and rivers, there are regions with higher productivity (e.g. fishery activity is concentrated in the northern part of the Aegean). The water mass of the south Aegean is of Levantine origin (LIW, Levantine Intermediate Water), which is typically oligotrophic

The sampling strategy was to sample 2 contrasting seasons. The first part of this study was carried out from 6 to 9 March 1997 in the southern Aegean Sea (eastern Mediterranean), during the first cruise of the MATER program, on the RV 'Aigaio' (Fig. 1, south Aegean MATER stations, Stns S1, S2, S6 and S7, depth 1300 to $2000 \mathrm{~m})$. In March in the south Aegean, the water column was well mixed, phosphate concentrations were $<0.05 \mu \mathrm{M}$ (Souvermetzoglou et al. unpubl. data) in the 0 to $100 \mathrm{~m}$ layer and water temperature was $15.0^{\circ} \mathrm{C}$. Water samples were collected in the euphotic zone at depths of 5,10,30,50,75 and $100 \mathrm{~m}$.

The second cruise was conducted from 9 to 23 September 1997. During this cruise, 6 stations were sampled for mixotrophic flagellates in the south (S1, S2, S3, S4, S6 and S7, depth 900 to $2200 \mathrm{~m}$ ) and 7 stations in the north Aegean (N1 to N7. depth 100 to $1200 \mathrm{~m}$ ). In 
September, the water column was stratified, the temperature in the south Aegean was approximately $23^{\circ} \mathrm{C}$ in the surface layer and $15^{\circ} \mathrm{C}$ at $100 \mathrm{~m}$ depth. In the north, water temperatures were 18 to $20^{\circ} \mathrm{C}$ and $15^{\circ} \mathrm{C}$ at the surface and $100 \mathrm{~m}$, respectively. The lower temperature and salinity in surface waters (salinity: 36.5 in the north versus 39.5 in the south) of the northern part is due to the influence of the Black Sea water. The $\mathrm{PO}_{4}$ concentrations were $<0.05 \mu \mathrm{M}$ in most cases, the highest $\mathrm{PO}_{4}$ concentration measured was $0.08 \mu \mathrm{M}$ in the north Aegean (Souvermetzoglou et al. unpubl. data)

Nanoplankton and picoplankton abundance, bacterial production. To enumerate phagotrophs among chlorophyll-containing nanoflagellates, we added fluorescent food tracer particles: FLM (Fluorescently Labelled Minicells) or FLB (Fluorescently Labelled Bacteria). The FLM (0.65 $\mu$ m diameter) were prepared following the protocol of Pace et al. (1990), the FLB were large cells (length 1.6 to $2.4 \mu \mathrm{m}, \mathrm{ESD} 0.8$ to $1.0 \mu \mathrm{m}$ ) and were prepared following the protocol of Sherr et al. (1987). Both FLM and FLB were briefly sonicated (30 s) on-board before every experiment to obtain monodispersed prey items. The final concentration of prey items in the experimental bottles was approximately $0.5 \times 10^{5} \mathrm{ml}^{-1}$. The uptake of FLB was evaluated only during the March cruise in the south Aegean for reasons that are explained below in the 'Results'.

Sampling was always conducted at 10:00 to 11:00 h. Acid-cleaned $150 \mathrm{ml}$ glass bottles were filled with seawater from each depth in duplicate (1 bottle for FLM and 1 for FLB). Before inoculation with the fluorescent tracers, bottles were left undisturbed for $1 \mathrm{~h}$ in a thermoregulated water bath. Incubation temperature in March was $15^{\circ} \mathrm{C}$ for all depths since the water column was well mixed. In September, because of the presence of the thermocline, we used 2 incubation temperatures corresponding to those above and below the thermocline.

After adding prey analogs, subsamples were immediately withdrawn for $T_{0}$ counts, and counts of bacteria, cyanobacteria, initial densities of tracer particles, and nanoplanktonic organisms. Samples were preserved with ice-cold glutaraldehyde at a final concentration of $2 \%$. Subsequent subsamples of $30 \mathrm{ml}$ were removed from bottles after 50 min to establish the abundance of mixotrophs. The time of $50 \mathrm{~min}$ was chosen to assure a 'maximal' uptake by phagotrophic organisms (Nygaard \& Tobiesen 1993, Havskum \& Hansen 1997), considering also that particle digestion of protists has been calculated to be 55 to $95 \mathrm{~min}$ for FLB at 12 to $16^{\circ} \mathrm{C}$ (Sherr et al. 1987). Samples were kept in the refrigerator and filtered $2 \mathrm{~h}$ after fixation on black Nuclepore filters $(0.2 \mu \mathrm{m}$ for picoplankton counts and $0.8 \mu \mathrm{m}$ for nanoplankton counts), stained with DAPI (Porter \&
Feig 1980) and stored at $-20^{\circ} \mathrm{C}$ until counting. All populations were enumerated using epifluorescence microscopy, autofluorescence was distinguished under blue (chlorophyll, labelled bacteria) and green (cyanobacteria) light excitation.

Among the nanoplankton in the size range 2 to $10 \mu \mathrm{m}$ we differentiated 3 functional groups: HN (Heterotrophic Nanoflagellates), PN (Phototrophic Nanoflagellates, i.e. all chloroplast-containing nanoplanktonic protists) and MN (Mixotrophic Nanoflagellates, i.e. chloroplast-containing nanoplanktonic protists with ingested particles). In the text when we refer to PN we mean total chloroplast-containing cells including $\mathrm{MN}$.

At least 150 to $250 \mathrm{HN}$ and PN were examined in each sample. This relatively low number is due to the low abundance of organisms (even with $30 \mathrm{ml}$ filtered) and was the best compromise between statistics and time spent on every sample examination. The organisms were classified in 4 different size categories $(2-3$, $3-5,5-7$ and $7-10 \mu \mathrm{m}$ ), using an ocular micrometer. Biovolume-carbon conversion factors were $250 \mathrm{fg} \mathrm{C}$ $\mathrm{um}^{-3}$ for cyanobacteria (Kana \& Glibert 1987), $220 \mathrm{fg} \mathrm{C}$ $\mu \mathrm{m}^{-3}$ for HN and PN (Børsheim \& Bratbak 1987). Bacterial abundance data were converted to biomass using $20 \mathrm{fg} \mathrm{C}$ cell $^{-1}$ (Lee \& Fuhrman 1987). Our choice of a factor of carbon content of bacteria, $20 \mathrm{fg} \mathrm{C}$ cell ${ }^{-1}$, is commonly employed. However, recent studies have underlined the uncertainties involved in applying a constant conversion factor, which for small cells could range between 5 and $40 \mathrm{fg} \mathrm{C} \mathrm{Cell}^{-1}$ (Theil-Nielsen \& Sondergaard 1998). In a recent paper, Robarts et al. (1996) calculated a carbon content of $15.1 \pm 3.7 \mathrm{fg} C$ for $87 \%$ and $24.1 \pm 15.6 \mathrm{fg} C$ for the remaining $13 \%$ of bacteria in the southeastern Mediterranean Sea. Hence, while the use of $20 \mathrm{fg} \mathrm{C} \mathrm{Cell}^{-1}$ in our study looks reasonable, bacterial biomass estimates should be interpreted with some caution.

Bacterial production. Bacterial production was estimated by the ${ }^{3} \mathrm{H}$-leucine method (Kirchman et al. 1986 , Kirchman 1993). At each depth, duplicate samples and a control were incubated with $1 \mathrm{nM} \mathrm{L}-\left[4,5{ }^{3} \mathrm{H}\right]$-leucine (specific activity $128 \mathrm{Ci} \mathrm{mmol}{ }^{-1}$ in March, $158 \mathrm{Ci}$ $\mathrm{mmol}^{-1}$ in September) $+19 \mathrm{nM}$ non radioactive leucine. Samples were incubated in the dark, at in situ temperature. Bacterial production was calculated according to Kirchman (1993) from ${ }^{3} \mathrm{H}$-leucine incorporation rates. Determination of the isotopic dilution factor is described below.

During the March cruise, time series experiments were carried out in order to choose the appropriate incubation time for a certain level of activity. We also performed concentration kinetic experiments to verify that the total concentration of leucine added (20 nM) was sufficient to saturate incorporation and, conse- 
Table 1. Mean population abundance ( $\pm \mathrm{SD}, \mathrm{n}=6$ depths) and bacterial production in the 0 to $100 \mathrm{~m}$ layer in the south and north Aegean

\begin{tabular}{|c|c|c|c|c|c|c|}
\hline Date (1997) & Stn & $\begin{array}{c}\text { Bacterial } \\
\text { abundance } \\
\left(10^{5} \mathrm{ml}^{-1}\right)\end{array}$ & $\begin{array}{c}\text { Bacterial } \\
\text { production } \\
\left(\mu \mathrm{C} \mathrm{Cl}^{-1} \mathrm{~d}^{-1}\right)\end{array}$ & $\begin{array}{c}\text { Phototrophic } \\
\text { nanoflagellates (PN) } \\
\left(10^{3} \mathrm{ml}^{-1}\right)\end{array}$ & $\begin{array}{c}\text { Heterotrophic } \\
\text { nanoflagellates (HN) } \\
\left(10^{3} \mathrm{ml}^{-1}\right)\end{array}$ & $\begin{array}{c}\text { Mixotrophic } \\
\text { nanoflagellates (MN) } \\
\left(10^{3} \mathrm{ml}^{-1}\right)\end{array}$ \\
\hline $\operatorname{Mar} 6$ & $\$ 2$ & $7.19 \pm 0.40$ & $0.78 \pm 0.19$ & $0.69 \pm 0.15$ & $0.30 \pm 0.04$ & $0.09 \pm 0.07$ \\
\hline 7 & S1 & $4.48 \pm 0.41$ & $0.72 \pm 0.11$ & $0.54 \pm 0.14$ & $0.25 \pm 0.05$ & $0.08 \pm 0.04$ \\
\hline 8 & $\mathrm{~S} 7$ & $10.71 \pm 1.9$ & $0.80 \pm 0.06$ & $0.64 \pm 0.16$ & $0.38 \pm 0.23$ & $0.05 \pm 0.02$ \\
\hline 9 & $\mathrm{~S} 6$ & $7.45 \pm 1.47$ & $0.64 \pm 0.27$ & $0.70 \pm 0.33$ & $0.43 \pm 0.11$ & $0.06 \pm 0.04$ \\
\hline Sep 9 & $\mathrm{~S} 4$ & $3.51 \pm 0.30$ & $0.56 \pm 0.09$ & $0.39 \pm 0.18$ & $0.86 \pm 0.17$ & $0.03 \pm 0.03$ \\
\hline 10 & S3 & $5.50 \pm 0.80$ & $0.76 \pm 0.19$ & $0.61 \pm 0.39$ & $1.01 \pm 0.44$ & $0.08 \pm 0.04$ \\
\hline 11 & S1 & $5.62 \pm 1.05$ & $0.54 \pm 0.09$ & $0.53 \pm 0.10$ & $0.87 \pm 0.20$ & $0.13 \pm 0.07$ \\
\hline 12 & $\mathrm{~S} 6$ & $7.46 \pm 1.32$ & $0.48 \pm 0.15$ & $0.81 \pm 0.47$ & $1.51 \pm 0.40$ & $0.10 \pm 0.03$ \\
\hline 13 & $\mathrm{~S} 7$ & $10.78 \pm 1.10$ & $0.49 \pm 0.12$ & $0.78 \pm 0.32$ & $1.46 \pm 0.35$ & $0.12 \pm 0.04$ \\
\hline 14 & $\mathrm{~S} 2$ & $8.39 \pm 1.76$ & $0.64 \pm 0.13$ & $0.87 \pm 0.33$ & $1.15 \pm 0.34$ & $0.07 \pm 0.02$ \\
\hline Sep 17 & N3 & $7.28 \pm 4.49$ & $0.41 \pm 0.27$ & $0.79 \pm 0.38$ & $0.60 \pm 0.14$ & $0.05 \pm 0.05$ \\
\hline 18 & $\mathrm{~N} 4$ & $7.11 \pm 1.67$ & $0.97 \pm 0.80$ & $1.28 \pm 0.46$ & $1.61 \pm 0.99$ & $0.08 \pm 0.07$ \\
\hline 19 & N1 & $7.09 \pm 3.77$ & $0.67 \pm 0.41$ & $0.95 \pm 0.24$ & $1.08 \pm 0.33$ & $0.12 \pm 0.06$ \\
\hline 20 & N2 & $7.38 \pm 2.48$ & $0.88 \pm 0.70$ & $0.95 \pm 0.22$ & $1.06 \pm 0.43$ & $0.09 \pm 0.06$ \\
\hline 21 & N6 & $6.89 \pm 2.37$ & $0.56 \pm 0.32$ & $1.03 \pm 0.16$ & $0.99 \pm 0.34$ & $0.12 \pm 0.05$ \\
\hline 22 & $N 7$ & $7.04 \pm 2.52$ & $1.18 \pm 0.71$ & $0.92 \pm 0.28$ & $1.07 \pm 0.40$ & $0.08 \pm 0.05$ \\
\hline 23 & N5 & $6.23 \pm 2.02$ & $1.16 \pm 1.10$ & $0.95 \pm 0.15$ & $1.26 \pm 0.91$ & $0.07 \pm 0.05$ \\
\hline
\end{tabular}

quently, to check that isotopic dilution would be negligible. For this purpose, we added constant concentrations of labelled leucine (1 nM) and 5 different concentrations of non radioactive leucine (1.8 to $37 \mathrm{nM}$ ). The plot of $T / f$ (inverse of radioactive leucine fraction incorporated per unit time) against leucine concentration allows the calculation of an index of isotopic dilution ( $x$ intercept) and the $V_{\max }$ (inverse of the slope, Pollard \& Moriarty 1984, Kirchman et al. 1986). Using the above concentration we found no isotopic dilution in the samples $(I D=1$, for more details about the method, see Van Wambeke et al. in press).

Enrichment experiment. Response of microbial populations to nutrient and/or carbon addition was examined in a small-scale enrichment experiment at Stn S1 in March. Inorganic nutrients and carbon were added to seawater from $50 \mathrm{~m}$ depth to stimulate the activity of both phytoplankton and heterotrophic bacteria. The concentrations of $\mathrm{NO}_{3}$ and $\mathrm{PO}_{4}$ before enrichment were $0.6 \mu \mathrm{M}$ and below detection limit (i.e. $<0.05 \mu \mathrm{M}$ ) respectively. Phosphates, nitrates and glucose were added individually and in all possible combinations: Co: control $=80 \mu \mathrm{m}$ screened water; $N$ : nitrates $1 \mu \mathrm{M}$; P: phosphate $0.5 \mu \mathrm{M}$; G: C-glucose $6 \mu \mathrm{M}$; NP: nitrate + phosphate NG: nitrate + glucose; PG: phosphate + glucose; NPG: nitrate + phosphate + glucose.

Within 1 h of collection, 8 acid-cleaned and sterilized 2 I polycarbonate bottles, 1 bottle per treatment, were filled with seawater from $50 \mathrm{~m}$. The water was gently filtered through $80 \mu \mathrm{m}$ to eliminate metazoans. After adding the nutrients, the bottles were placed in an on- deck incubator with circulating surface seawater, and covered with a neutral screen providing $50 \%$ light attenuation. The concentrations of nutrients in the experimental bottles were measured at time $0 \mathrm{~h}$ with a technicon analyzer. Subsamples of $30 \mathrm{ml}$ for $\mathrm{HN}$ and PN counting were removed at $T_{0}, T_{24}, T_{48}$. Subsamples $(200 \mathrm{ml})$ for ingestion experiments to estimate abundance of MN were removed at time $T_{0}$ and $T_{48}$. Bacterial numbers and bacterial production were measured at $T_{0}, T_{6}, T_{12}, T_{24}, T_{36}$ and $T_{48}$.

\section{RESULTS}

\section{Vertical distribution of $\mathrm{MN}, \mathrm{PN}, \mathrm{HN}$, bacteria and bacterial production}

\section{March}

In early spring (5 to 11 March 1997) in the south Aegean, vertical gradients were weak; data reported below are in the form of overall sample averages for March $(n=24)$. Bacteria were found in concentrations of about $0.7 \times 10^{6}$ cells $\mathrm{mI}^{-1}$ and bacterial production

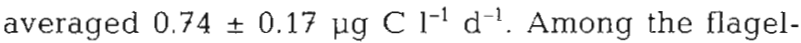
lates, PN were numerically dominant, representing $65 \%$ of total flagellates (Table 1, Fig. 2a).

FLB and FLM were ingested by protists at different rates. While $60 \pm 11 \%$ of HN contained FLM after $1 \mathrm{~h}$ of incubation, they did not ingest FLB at all. Among PN, $12 \%$ took up FLM. FLB ingestion by PN and inges- 
tion of naturally occurring Synechococcus was checked in 18 samples ( 3 stations, all depths). Synechococcus were present in concentrations of about $0.2 \times 10^{5}$ cells $\mathrm{ml}^{-1}$. From a total of $1567 \mathrm{PN}$ cells observed, $6.2 \pm 1.7 \%$ took up FLB, while only $2.9 \pm$ $2.3 \%$ were found to contain 'Synechococcus-like' cyanobacteria. The low rates of FLB consumption are probably due to their large size and the small size of flagellates (mostly 2 to $3 \mu \mathrm{m}$ ). Therefore, in the results below, for both estimation of MN numbers and calculation of bacterivory rates only the FLM ingestion is considered.

MN concentrations generally followed the same distribution trend as total phototrophs (PN) indicating that mixotrophs appeared to be a relatively constant proportion (about $12 \%$ ) of PN and about $23 \%$ of the typical bacterivores, HN. The mean biomass in the 0 to $100 \mathrm{~m}$ layer was $4.9 \pm 2.8,2.2 \pm 1.25$ and $0.53 \pm 0.3 \mu \mathrm{g}$ $\mathrm{C} \mathrm{I}^{-1}$ for PN, HN, MN respectively. In terms of size distributions, the nanoplanktonic community was composed largely of small cells $<5 \mu \mathrm{m}$. MN were almost exclusively represented by Prymnesiophyceae-like organisms 2 to $4 \mu \mathrm{m}$.

\section{September}

In September, there were differences in the vertical distributions of different types of nanoflagellates. HN were more abundant than PN in the upper layer and declined to low concentrations below the thermocline (Fig, 2b,c). In terms of overall average concentrations, HN abundance was similar in the north and the south (Table 1), while PN abundance was slightly higher in the north. In the north stations influenced by the Black Sea water (BSW), we found high bacterial production in the surface waters. The highest bacterial production was measured at $5 \mathrm{~m}$ depth at Stn $\mathrm{N} 5$ and was $2.9 \mu \mathrm{g} \mathrm{C}$

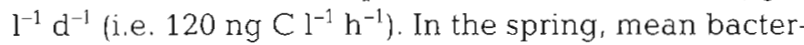
ial production in the 0 to $100 \mathrm{~m}$ layer was $0.74 \pm 0.17 \mathrm{\mu g}$ $\mathrm{C}^{-1} \mathrm{~d}^{-1}$ for the south. Late summer mean values ( 9 to 23 September 1997) were close to those of March: $0.58 \pm 0.15$ and $0.82 \pm 0.64 \mu \mathrm{C} \mathrm{Cl}^{-1} \mathrm{~d}^{-1}$ in the south and in the north respectively. Thus, the mean bacterial production was similar in the north and the south, however the variability between the north stations was pronounced. Despite all these differences, the abundances of $\mathrm{MN}$ were very similar in the south and north Aegean, 0.03 to $0.18 \times 10^{3} \mathrm{ml}^{-1}$, and were similar to those recorded for March. The relative contribution of mixotrophs to total nanoflagellate abundance was $5 \%$, and relative to the total phototrophs, MN equaled $13 \%$ in the south and $9 \%$ in the north.

Compared to March, average cell size of nanoflagellates was larger with a shift in size distribution towards

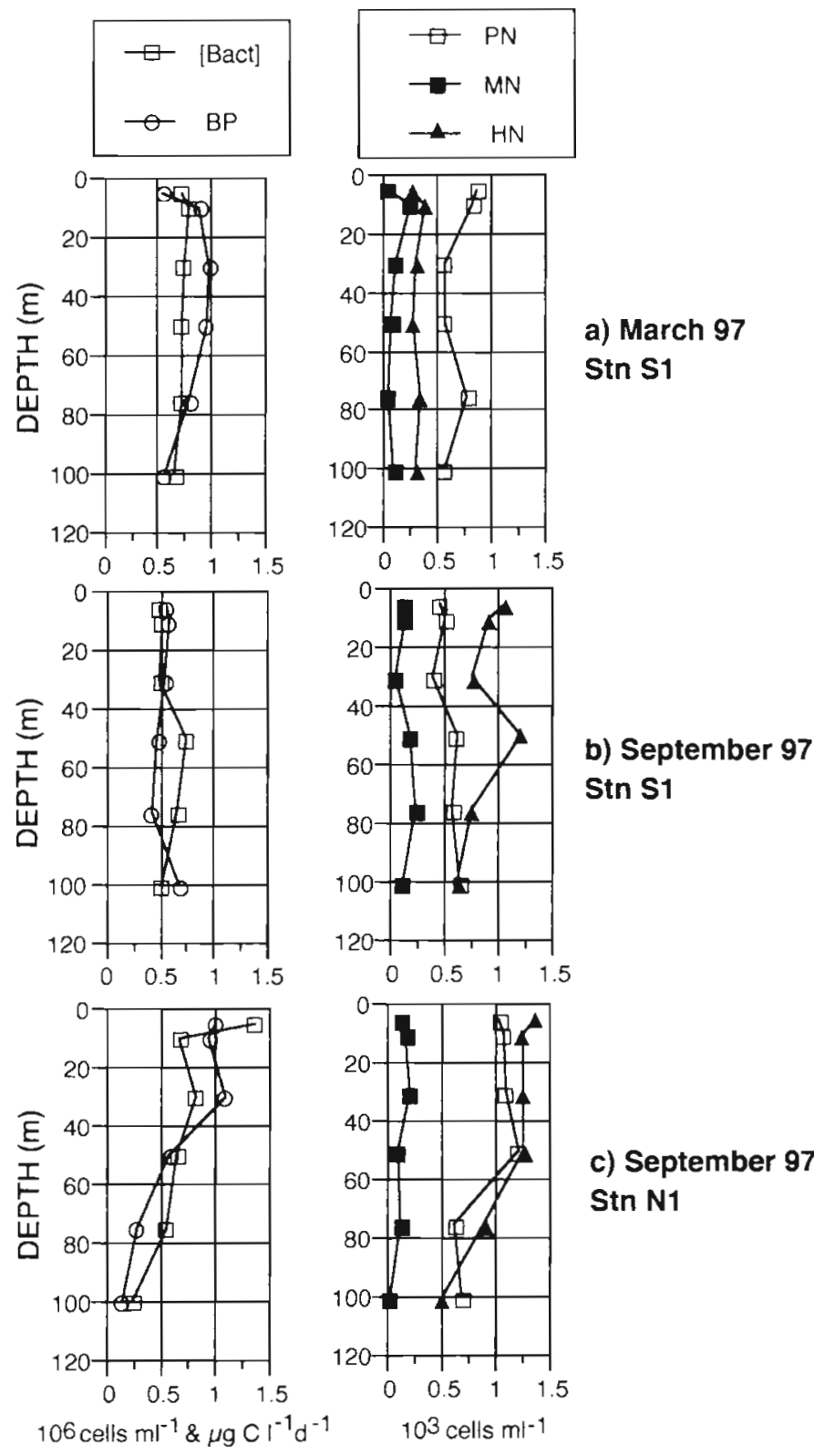

Fig. 2. Typical vertical profiles of HN (heterotrophic nanoflagellates), PN (phototrophic nanoflagellates = all chloroplast containing flagellates), $\mathrm{MN}$ (mixotrophic nanoflagellates = PN with ingested minicells), bacterial numbers and bacterial production in (a) March 1997, south Aegean, Stn S1, (b) September 1997, south Aegean, Stn S1, (c) September 1997, north Aegean, Stn N1

organisms 8 to $10 \mu \mathrm{m}$. The dominance of 8 to $10 \mu \mathrm{m}$ organisms was more pronounced for the PN population. The $M N$, in contrast to the March community, were composed of a variety of sizes and morphotypes and in terms of biomass, 8 to $10 \mu \mathrm{m}$ size cells dominated the MN community.

The mean biomasses in the 0 to $100 \mathrm{~m}$ layer were $6.4 \pm 4.0,7.6 \pm 4.2$ and $1.8 \pm 1.5 \mu \mathrm{g} \mathrm{C} \mathrm{l}^{-1}$ for PN, HN, 


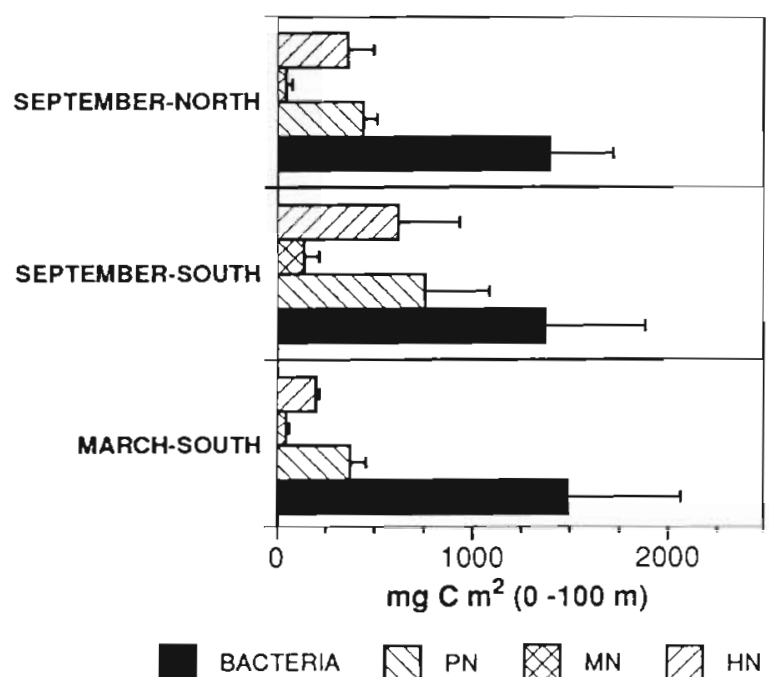

Fig. 3. Mean integrated biomass of heterotrophic bacteria and nanoflagellate groups. HN (heterotrophic nanoflagellates), PN (phototrophic nanoflagellates = all chloroplast containing flagellates), MN (mixotrophic nanoflagellates = PN with ingested minicells)

$M N$ respectively in the south; and $4.4 \pm 2.9,4.6 \pm 2.8$ and $0.5 \pm 0.5 \mu \mathrm{g} \mathrm{C} \mathrm{I}^{-1} \mathrm{PN}, \mathrm{HN}, \mathrm{MN}$ respectively in the north. In the south, the relative biomass of $\mathrm{MN}$ was 15 and $23 \%$ of $\mathrm{PN}$, and 31 and $27 \%$ of $\mathrm{HN}$ in March and September, respectively. In the north the MN relative biomass was lower, 10 and $11 \%$ of the PN and $H N$, respectively.

The mean integrated biomass of $H N, P N, M N$ in the 3 cases studied showed that generally the MN biomass was 10 to $20 \%$ of the total biomass of PN (Fig. 3). MN biomass was 10 to $30 \%$ of the biomass of HN which are the typical bacterivores. The integrated bacterial biomasses were similar in the 3 cases studied: $1611 \pm$ $287 \mathrm{mg} \mathrm{C} \mathrm{m}^{-2}$ in March 97 in the south, and $1559 \pm 208$ and $1366 \pm 65 \mathrm{mg} \mathrm{C} \mathrm{m}^{-2}$ in September, in the south and the north respectively

Table 2. $t$-test for comparisons of microbial parameters in north and south Aegean in September 1997 (df = 76). 'Statistícally non significant. Chl a from Ignatiades et al. (unpubl.)

\begin{tabular}{|lcc|}
\hline Parameter & $t$-test & $\mathrm{p}$ \\
\hline Heterotrophic nanoflagellate number (HN) & 0.39 & $0.696^{\circ}$ \\
Phototrophic nanoflagellate number (PN) & 4.31 & 0.0001 \\
Mixotrophic nanoflagellate number (MN) & 0.32 & $0.741^{\circ}$ \\
Bacterial number & 0.20 & $0.83^{\circ}$ \\
Bacterial production & 3.35 & 0.001 \\
Chl a & 3.17 & 0.0001 \\
Heterotrophic nanoflagellate biomass (HN) & 3.40 & $0.0011^{\circ}$ \\
Phototrophic nanoflagellate biomass (PN) & 2.42 & $0.012^{\circ}$ \\
Mixotrophic nanoflagellate biomass (MN) & 4.49 & 0.0001 \\
\hline
\end{tabular}

\section{Comparison of north and south basins (September)}

We compared microbial parameters in the north and south Aegean using the September data. While no differences were found for $\mathrm{HN}, \mathrm{MN}$ and bacterial abundance, the t-test analysis (Table 2) suggested there were significant differences in $P N$ abundance, bacterial production, and $\mathrm{HN}, \mathrm{PN}$ and $\mathrm{MN}$ biomasses between the north and the south Aegean.

We then tested the variability among northern stations for given depths and variability among southern stations for given depths (Table 3 ). The south appeared relatively homogenous. Based on the September data, there were no differences among southern stations for the microbial parameters tested ( $\mathrm{HN}, \mathrm{PN}, \mathrm{MN}$ numbers and biomass, bacterial numbers and production) but for the northern stations there was significant variability between stations for most of the parameters tested (Table 3). Finally, we examined the relationships between microbial parameters in the north and the south Aegean using correlation analysis (Table 4). In March, when data were gathered only for the south Aegean, the single significant relationship was between HN and bacterial concentration. The north and south stations were analyzed separately using the September data. For both areas, some of the most highly correlated parameters were between $H N$ and bacterial abundance and between concentrations of $\mathrm{HN}$ and PN. In the north, in contrast to the south, HN concentrations were significantly related to bacterial production (Table 4).

\section{Estimates of bacterivory relationships with bacterial production}

Minimal estimates of bacterivory and $C$ flow were calculated based on minicell ingestion. We call these

Table 3. ANOVA for comparisons of microbial parameters between stations in the north Aegean in September 1997 (df = 41). - Statistically non significant. No statistical differences were found in the south Aegean. Chl a from Ignatiades et al. (unpubl.)

\begin{tabular}{|lcl|}
\hline Parameter & F-value & $\mathrm{p}$ \\
\hline Heterotrophic nanoflagellate number (HN) & 5.60 & 0.0006 \\
Phototrophic nanoflagellate number (PN) & 1.62 & $0.17^{\circ}$ \\
Mixotrophic nanoflagellate number (MN) & 3.67 & 0.0087 \\
Bacterial number & 8.31 & 0.0001 \\
Bacterial production & 5.96 & 0.0004 \\
Chl a & 3.76 & 0.0076 \\
Heterotrophic nanoflagellate biomass (HN) & 3.84 & 0.0068 \\
Phototrophic nanoflagellate biomass (PN) & 5.30 & 0.0009 \\
Mixotrophic nanoflagellate biomass (MN) & 2.28 & $0.067^{\circ}$ \\
\hline
\end{tabular}


Table 4. Significant correlations between microbial parameters including chl a. $\mathrm{r}^{2}=$ Spearman's rho. Correlations common in the north and the south in September 1997. Chl a from Ignatiades et al. (unpubl.)

\begin{tabular}{|c|c|c|c|c|c|}
\hline Parameter & $r^{2}$ & $\mathrm{p}$ & Parameter & $r^{2}$ & $\mathrm{p}$ \\
\hline North, Sep $(n=42)$ & & & South, Sep $(n=36)$ & & \\
\hline HN number - PN number & 0.36 & 0.00001 & HN number - Chl a & 0.39 & 0.0001 \\
\hline HN number - Bact. number & 0.15 & 0.01 & HN number - Bact. number ${ }^{\circ}$ & 0.29 & 0.0007 \\
\hline HN number - Bact. production & 0.58 & 0.0001 & HN number - PN biomass ${ }^{\circ}$ & 0.29 & 0.0007 \\
\hline HN number - PN biomass ${ }^{*}$ & 0.52 & 0.0001 & PN number - Chl a & 0.30 & 0.0005 \\
\hline PN number - MN number & 0.39 & 0.0001 & Bact. production - PN biomass ${ }^{\circ}$ & 0.23 & 0.003 \\
\hline PN number - Bact. production & 0.22 & 0.001 & Bact. production - HN biomass & 0.21 & 0.004 \\
\hline PN number - HN biomass & 0.16 & 0.007 & Bact. production - $\mathrm{MN}$ biomass & 0.22 & 0.004 \\
\hline PN number - $M N$ biomass & 0.17 & 0.006 & PN biomass - HN biomass & 0.27 & 0.001 \\
\hline MN number - HN biomass & 0.28 & 0.0003 & PN biomass - $\mathrm{MN}$ biomass & 0.23 & 0.003 \\
\hline Bact. number - Bact production & 0.15 & 0.0002 & HN biomass - MN biomass ${ }^{\circ}$ & 0.49 & 0.0001 \\
\hline Bact. production - PN biomass ${ }^{\circ}$ & 0.31 & 0.0001 & South, Mar $(n=24)$ & & \\
\hline HN biomass - $\mathrm{MN}^{\prime}$ biomass ${ }^{\circ}$ & 0.28 & 0.0003 & HN number - Bacteria & 0.31 & 0.004 \\
\hline
\end{tabular}

estimates 'minimal' because minicells may be discriminated against by mixotrophs as well as heterotrophs.

In our experiments, $60 \pm 11 \%$ of HN were found to contain minicells. The range of ingested minicells by HN was 1 to $4 \mathrm{FLM} \mathrm{HN}^{-1} \mathrm{~h}^{-1}$, while the minicells ingested by $M N$ rarely exceeded $2 \mathrm{FLM} \mathrm{MN}^{-1} \mathrm{~h}^{-1}$. We cannot know what \% of MN discriminated against minicells because their recognition is based on the ingestion of these fluorescent prey (see 'Materials and methods'). The overall mean clearance rate (CR) based on rates of FLM consumption by $\mathrm{HN}$ was higher than that of MN $\left(2.6 \pm 0.78\right.$ and $1.8 \pm 0.60 \mathrm{nl}$ flagellate $^{-1} \mathrm{~h}^{-1}$ respectively). Clearance rates of both $\mathrm{HN}$ and $\mathrm{MN}$ declined with increasing concentrations of bacteria, based on station averages (Fig. 4).

To compare bacterial production with consumption rates, we calculated bacterivory in carbon units. For each station, we used the average clearance rate, bacterial concentration, and a bacteria carbon content factor of $20 \mathrm{fg} \mathrm{C}$ per bacterium. Nanoflagellate bacterivory accounted for about $40 \%$ of bacterial production in March, while in September bacterial production for both basins $\left(0.58\right.$ and $0.83 \mu \mathrm{g} \mathrm{C} \mathrm{I}^{-1} \mathrm{~d}^{-1}$ in the southern and northern basin respectively) roughly balanced estimated nanoflagellate consumption (Fig. 5). Bacterial grazing due to mixotrophic flagellates represented about $5 \%$ of the total nanoflagellate bacterivory in both March and September experiments.

\section{Microbial responses to nutrient and carbon enrichment}

After 48 h of incubation, the number of MN, PN and $\mathrm{HN}$ in the control bottles slightly increased $(13,7,17 \%$ respectively). Relative to the control, the number of 'phagotrophically active' algae decreased in all incu- bations, however the decrease was pronounced in the phosphate amended bottles (Fig. 6). PN numbers varied little while HN showed a slight decrease in N, NP, PG and NPG amended bottles. No change in HN numbers was observed in $\mathrm{P}$ or NG, while a slight increase was observed in the G-spiked bottle.

Bacterial numbers increased by 20 to $40 \%$ in all treatments relative to the $0 \mathrm{~h}$ control. In absolute numbers, the bacterial production in the control increased by a

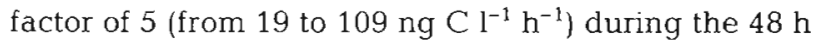
incubation (confinement effect). 'Bottle or confinement effects' are commonly reported and a variety of explanations have been suggested (Ferguson et al. 1984, Morita 1997 and references therein). The prevailing explanation is that nutrients are absorbed and concentrated onto surfaces and thus become more utilizable by bacteria. However, another explanation is that the increase of bacterial population in the control during the first days of 'confinement' is due to a perturbation of their predators. In our experience, using oligotrophic water

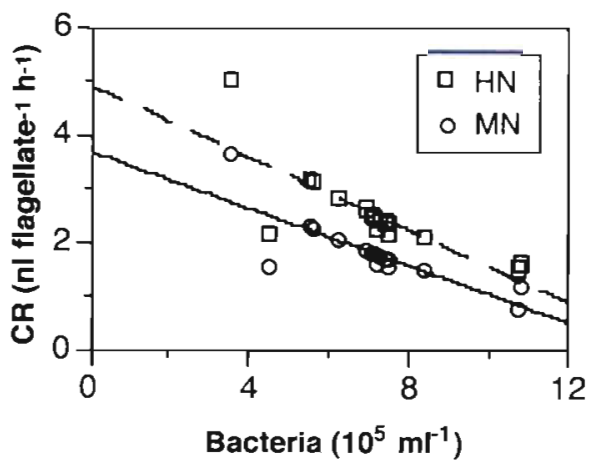

Fig. 4. Estimates of clearance rates plotted against bacterial concentration (averages per station: 6 depths) for heterotrophic nanoflagellates (HN) and mixotrophic nanoflagellates ( $\mathrm{MN}$ ) based on ingestion of FLM. Solid line for $\mathrm{MN}$, broken line for HN values 


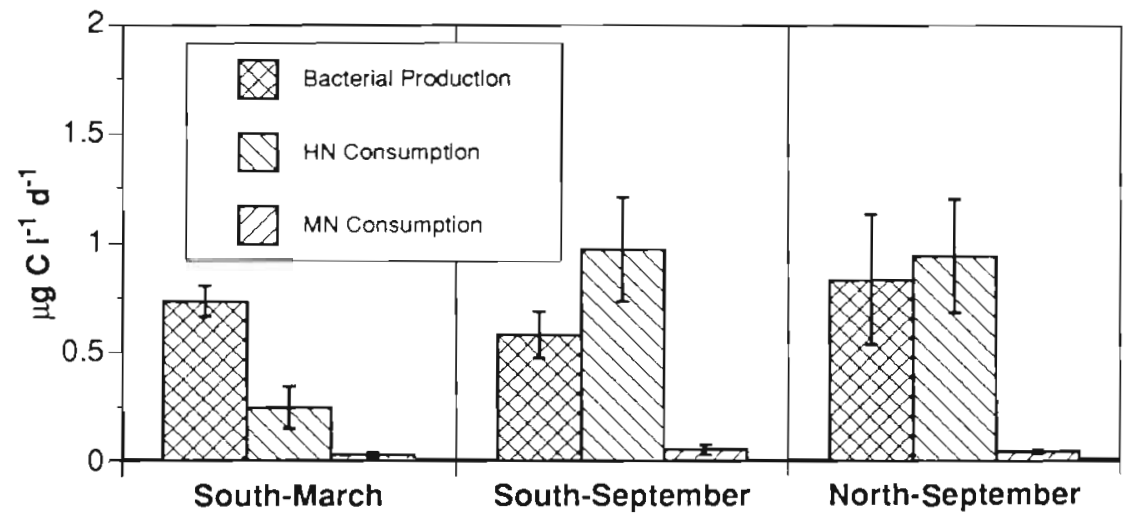

Fig. 5. Estimates of bacterivory and C flow based on minicell ingestion by heterotrophic and mixotrophic nanoflagellates. Bacterial production estimated using the leucine method. Consumption was estimated by calculating ingestion in terms of bacteria ingested flagellate $\mathrm{h}^{-1}$ from clearance rate (based on FLM ingestion) times bacterial concentration and converted to carbon units using $20 \mathrm{fg} C$ bacterium $^{-1}$ Depth-averaged rates were calculated for each station, error bars represent the SD between station averages samples, heterotrophs often show negative or zero growth immediately following confinement. In either way, the bottle effect has to be considered in the design
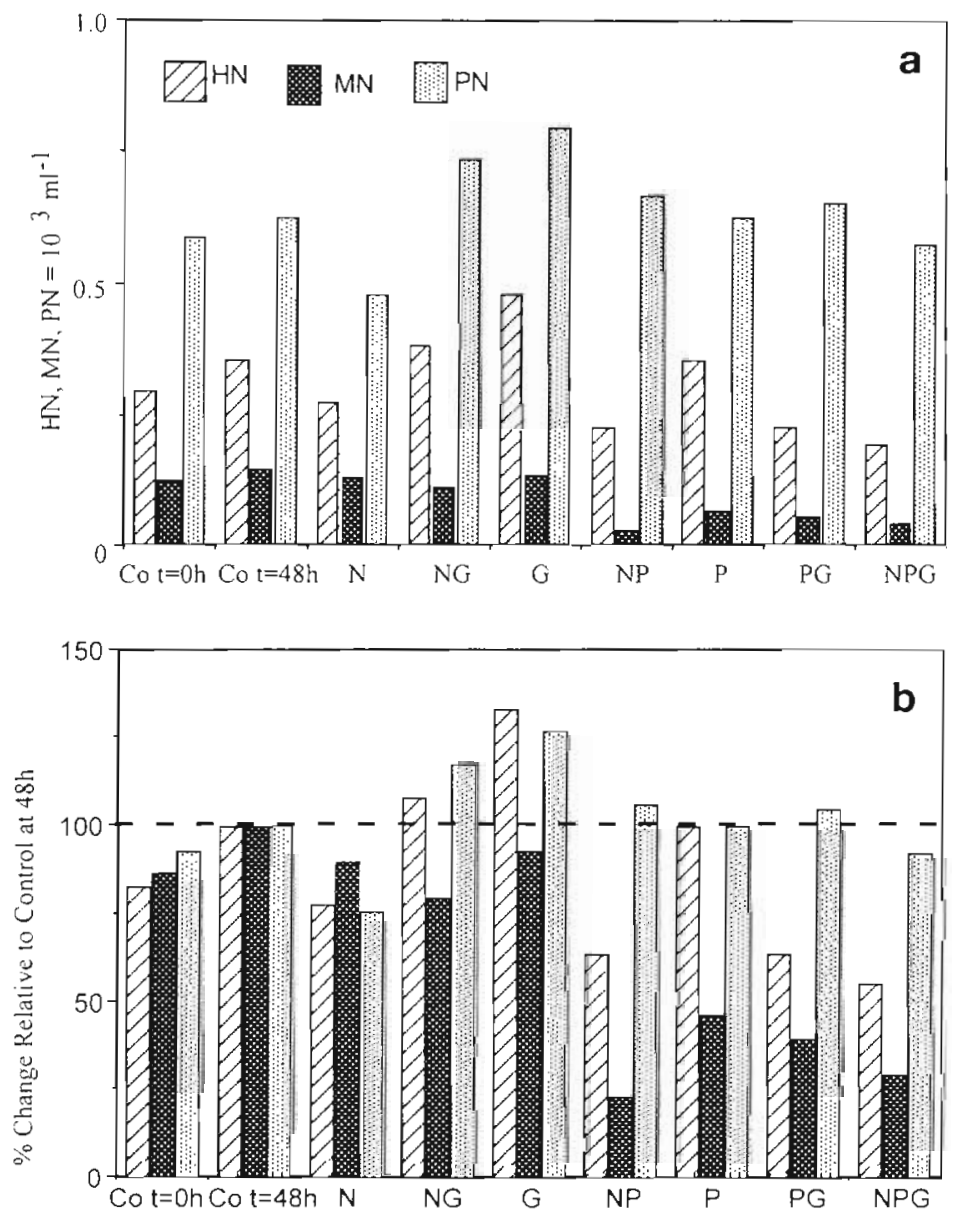

Fig. 6. Flagellate populations in the enrichment experiment in the south Aegean, March 1997. Stn S1. Co: control $=80 \mu \mathrm{m}$ screened wateri $\mathrm{N}$ : nitrates $1 \mu \mathrm{M}$; : phosphate $0.5 \mu \mathrm{M}$; G: glucose $6 \mu \mathrm{M} \mathrm{C}$-glucose; NP: nitrate + phosphate; NG: nitrate + glucose; PG: phosphate + glucose; NPG: nitrate + phosphate + glucose. (a) Absolute numbers of flagellates, heterotrophic nanoflagellates, HN, mixotrophic nanoflagellates, MN, and phototrophic nanoflagellates, PN. (b) Changes, in percent, relative to the control bottle at $48 \mathrm{~h}$ and interpretation of bottle experiments. For this reason, whilst we give values of the control bottles at 0 and $48 \mathrm{~h}$, we also make comparisons for the 48 h values.

The integrated bacterial production for the 48 h of incubation (Fig. 7) showed little change relative to the control in $N$ and $G$ bottles and the increase in NG-spiked bottle was of the order of $30 \%$. In contrast, bacterial production increased in P, PG and NPG by a factor of 3,5,7 respectively (360 to $700 \%$, Fig. 7). While treatments were unreplicated, the 4 bottles which received phosphorus, either alone with $\mathrm{N}$ or glucose or both, showed high bacterial production and low concentrations of phagotrophically active $\mathrm{PN}$, i.e. $\mathrm{MN}$ (Figs. $6 \& 7$ ).

\section{DISCUSSION}

We found bacterial production in the Aegean Sea in the 0 to $100 \mathrm{~m}$ layer to average about $74 \mathrm{mg} \mathrm{C} \mathrm{m}^{-2} \mathrm{~d}^{-1}$. Our values are close to previous measurements of bacterial production made in open sea stations of the Cretan Sea (60 to $70 \mathrm{mg} \mathrm{C} \mathrm{m} \mathrm{m}^{-2} \mathrm{~d}^{-1}$, Van Wambeke et al. in press) but are somewhat higher than estimates made for the Levantine basin, 8.2 to $43.4 \mathrm{mg} \mathrm{C} \mathrm{m}^{-2} \mathrm{~d}^{-1}$ (0 to $200 \mathrm{~m}$ layer, Robarts et al. 1996). These values of bacterial production, compared to estimates of primary production for the Aegean Sea of about $68 \mathrm{mg} \mathrm{C} \mathrm{m}^{-2} \mathrm{~d}^{-1}$ (Ignatiades 1998), confirmed our expectations concerning the importance of heterotrophic bacterial production in such an oligotrophic system. However, despite low absolute concentrations of bacteria, bacterivory appeared to be dominated by HN rather than MN.

A possible source of error in our estimates of bacterivory is discrimination against prey analogs, by $\mathrm{MN}$ or HN. Nanoflagellates are known to be capable of selective feeding, dis- 
tinguishing for example, between inert particles or live and heat-killed bacteria (Nygaard et al. 1988, Landry et al. 1991) with selectivity varying with the availability of prey (e.g. Jürgens \& DeMott 1995, Dolan \& Simek 1998). Hence, it would not be unreasonable to suppose that FLM ingestion rates could underestimate true bacterivory. However, while HN bacterivory left a substantial amount of bacterial production unconsumed in March, it closely matched estimates of bacterial production in September (Fig. 5).

Our analysis of microbial parameters suggested significant differences between the southern and northern stations (Table 2). We found little variance between stations in the south but significant variability among northern stations (Table 3). Given these results and differences in the relationships between microbial parameters in the north and south (Table 4), the 2 appear to be distinct systems, probably reflecting the input of Black Sea water in the north. In the south, where there was little station to station variability, there were fewer significant relationships, Spearman's rho values were low, and bacterivory - considered as biomass of $\mathrm{HN}$ or $\mathrm{MN}$ - was weakly linked to bacterial production or concentration. In contrast, among samples gathered from northern stations, HN concentrations were relatively strongly correlated with bacterial production (Spearman's rho $=0.58$, Table 4).

Clearance rate estimates based on FLM ingestion fell within the typical figures reported of a few $\mathrm{nl}_{\text {cell }}{ }^{-1} \mathrm{~h}^{-1}$ (e.g. Eccleston-Parry \& Leadbeater 1994, Gonzalez 1996). Interestingly, in both $\mathrm{HN}$ and $\mathrm{MN}$ populations, clearance rates appeared to decline with bacterial concentration (Fig. 4). Such a pattern may reflect an adaptation to low prey concentrations or, alternatively, a discrimination against FLM increasing with ambient bacterial prey concentration.

We found that mixotrophs were not the dominant consumers of heterotrophic bacteria and were a small part of the community of phototrophic nanoplankton. Our findings are similar to those concerning the nanoflagellate community of the oligotrophic Sargasso Sea. Arenovski et al. (1995) reported that only a few percent of the phototrophic nanoplankton ingested bacteriasized particles in surface waters of the Sargasso Sea. In phosphorus-depleted surface waters of a Norwegian fjord, mixotroph feeding on picoplankton was undetectable, although consumption of larger food items by some small dinoflagellates was estimated (Havskum \& Hansen 1997).

The relative contribution of bacterivory to the growth of mixotrophs is still poorly understood. While mixotrophic algae are abundant in a variety of aquatic habitats, few generalities have emerged. Bacterivory by these organisms may vary as a function of environmental factors, such as nutrient availability, light,
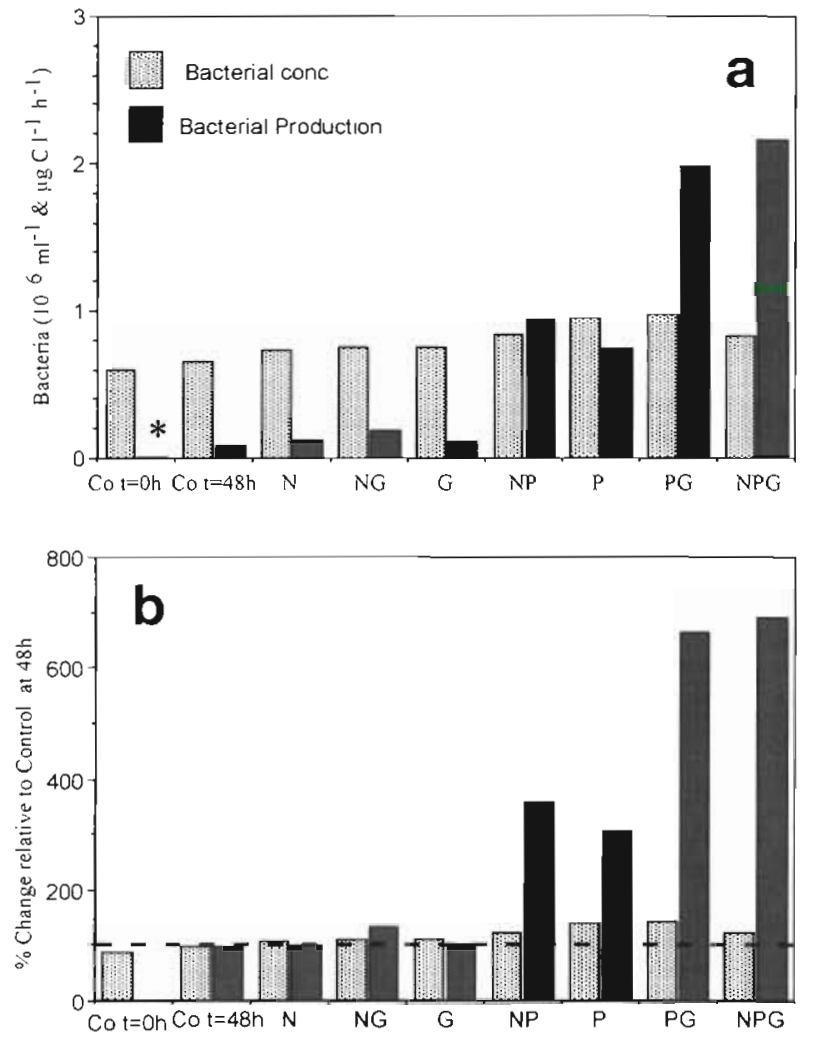

Fig. 7. Heterotrophic bacteria in the enrichment experiment in the south Aegean, March 1997. Stn S1. Co: control $=80 \mu \mathrm{m}$ screened water; $\mathrm{N}$ : nitrates $1 \mu \mathrm{M}$; P: phosphate $0.5 \mu \mathrm{M}_{i} \mathrm{G}$ : glucose $6 \mu \mathrm{M}$ C-glucose; NP: nitrate + phosphate; NG: nitrate + glucose; PG: phosphate + glucose; NPG: nitrate + phosphate + glucose. (a) Absolute numbers of bacteria and production rates at $0 \mathrm{~h}$ (control) and $48 \mathrm{~h}$ (control and spiked bottles); (*)

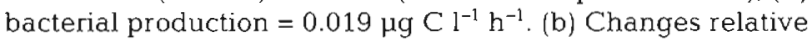
to the control bottle; integrated bacterial production is expressed in $\mu \mathrm{g} \mathrm{Cl}^{-1} \Delta t$, where $\Delta t=48 \mathrm{~h}$

salinity etc, and of course species-specific preferences explaining variability between observations and sometimes conflicting results (e.g. review by Riemann et al. 1995, Legrand et al. 1998 and references therein). For example, in the Bay of Aarhus (Denmark), in coastal waters of New Zealand during an upwelling event, in a Norwegian fjord during the end of a bloom and in Boston Harbor (USA), bacterivory was dominated by MN (Epstein \& Shiaris 1992, Hall et al. 1993, Nygaard \& Tobiesen 1993, Havskum \& Riemann 1996). Mixotrophs are common in freshwater eutrophic systems (e.g. Bennet et al. 1990, Sanders 1991), but in a comparison of lakes of differing trophic status, Berninger et al. (1992) found bacterivory by mixotrophs to be most important in mesotrophic rather than oligotrophic or eutrophic lakes.

Mixotrophs of the Aegean Sea probably gain carbon from bacterivory, an amount equivalent to approximately 4 to $10 \%$ of their own cell carbon per day, based 
on our estimates of clearance rates. This suggests, unless we have severely underestimated mixotroph clearance rates, that they probably do not profit significantly from the carbon ingested but may practice phagotrophy to obtain nutrient salts. Evidence in support of this view was found in the enrichment experiment. While individual treatments were unreplicated, all the bottles which received phosphorus showed marked decreases in abundance of phagotrophically active PN-mixotrophs, as well as increases in bacterial production and concentrations (Figs. $6 \& 7$ ). The results from the enrichment experiment support the view of the Mediterranean as a phosphorus-limited marine system (Dolan et al. 1995, Thingstad et al. 1998) with the eastern Mediterranean as severely phosphoruslimited (Krom et al, 1993, Zohary \& Robarts 1998). Declines in phagotrophic activity by mixotrophs when nutrients are plentiful have been reported by others (e.g. Arenovski et al. 1995, Rothhaupt 1996, Legrand et al. 1998). Interestingly, nutrient enrichment experiments with Sargasso Sea populations gave very similar results to ours, with marked declines in phagotrophically active $\mathrm{PN}$ in treatments including phosphorus additions (Arenovski et al. 1995).

Thus, mixotrophic algae are indeed commonly found in the oligotrophic eastern Mediterranean. These primary producers play a role as potential bacterivores and should be considered in the assessments of the flows of material between compartments of the planktonic food web. We found that phagotrophic activity of algae in the Aegean may be related to the concentration of nutrients in the water (e.g. phosphorus).

To our knowledge, the data presented here are some of the first concerning evidence of selective feeding among natural populations of marine MN. We found some indications of size-selection: PN ingested FLM $(\varnothing 0.65 \mu \mathrm{m}$ ) at higher rates than FLB (length 1.6 to $2.4 \mu \mathrm{m}, \mathrm{ESD} 0.8$ to $1.0 \mu \mathrm{m}$ ) and more PN ingested FLB than were found containing naturally occurring Synechococcus sp. cells $(\varnothing 1.0 \mu \mathrm{m})$. Interestingly, HN feeding on heterotrophic bacteria generally show increases in clearance rates with increasing prey size (e.g. Gonzalez 1996). However, very large bacteria are often not ingested (e.g. Simek \& Chrzanowski 1992) and thus clearance rates decrease when prey volumes exceed 0.6 to $1.2 \mu \mathrm{m}^{3}$ (Jürgens \& Gude 1994). Clearly, discrimination among prey items may have been on a basis other than size alone given that some nanoflagellates feed at higher rates on living versus heat-killed bacteria (Monger \& Landry 1992). However, $M N$ in the eastern Mediterranean, given their small sizes, simply may not feed efficiently on large bacteria.

Clearly, much work remains concerning MN. Future investigations on mixotrophic flagellates should probably be oriented towards examinations of feeding behavior in relation to other environmental factors such as the availability of trace elements or light as well as their physiological state.

Acknowledgements. Financial support was provided by the Commission of the European Communities through the contracts MATER (MAST 3, PL 95-0401), KEYCOP (MAS 3 - CT 97-0148). We thank Lydia Ignatiades and colleagues, and Katerina Souvermetzoglou and colleagues for providing unpublished chlorophyll and nutrient data. We are grateful to Harry Havskum and Celia Marrasé for kindly providing the FLB and minicells. We also thank Vassilis Zervakis for help with Fig. 1 and useful discussions, and the captain and the crew of RV 'Aigaio' for their assistance and good mood. This is an MTP II MATER contribution no. 29.

\section{LITERATURE CITED}

Arenovski AL, Lim EL, Caron DA (1995) Mixotrophic nanoplankton in oligotrophic surface waters of the Sargasso Sea may employ phagotrophy to obtain major nutrients. J Plankton Res 17:801-820

Balopoulos E, Varnavas S, Monaco A, Price NB, Collins MB, Kotsovinos N, Matsoukis P, Dermissis V, Apostolopoulou $M$ (1997) Hydrodynamics and biochemical fluxes in the straits of the Cretan Arc Aegean Sea, eastern Mediterranean Basin. MTP-Pelagos. In: Lipiatou E (ed) Interdisciplinary research in the Mediterranean Sea. A synthesis of scientific results from the Mediterranean targeted project phase I, 1993-1996. European Communities DGXII, Brussels, p 93-119

Bennet SJ, Sanders RW, Porter KG (1990) Heterotrophic, autotrophic and mixotrophic ranoflagellates: seasonal abundances and bacterivory in a eutrophic lake. Limnol Oceanogr 35:1821-1832

Berninger UG, Caron DA, Sanders RW (1992) Mixotrophic algae in three ice-covered lakes of the Pocono Mountains USA. Freshw Biol 28:263-272

Børsheim KY, Bratbak G (1987) Cell volume to cell carbon conversion factors for a bacterivorous Monas sp. enriched from sea water. Mar Ecol Prog Ser 36:171-175

Dolan JR, Simek K (1998) Ingestion and digestion of an autotrophic picoplankter Synechococcus, by a heterotrophic nanoflagellate, Bodo saltans. Limnol Oceanogr 43: $1740-1746$

Dolan JR, Thingstad TF, Rassoulzadegan F (1995) Phosphate transfer between microbial size-fractions in Villefranche Bay (N. W. Mediterranean Sea) France in autumn 1992. Ophelia 41:71-8.5

Eccleston-Parry JD, Leadbeater BSC (1994) A comparison of the growth kinetics of six marine heterotrophic nanoflagellates fed with one bacterial species. Mar Ecol Prog Ser 105:167-177

Epstein SS, Shiaris M (1992) Size-selective grazing of coastal bacterioplankton by natural assemblages of pigmented flagellates, colorless flagellates, and ciliates. Microb Ecol 23:211-225

Fenchel T (1982) Ecology of heterotrophic microflagellates. IJ. Bioenergetics and growth. Mar Ecol Prog Ser 8:225-231

Ferguson RL, Buckley EN, Palumbo AV (1984) Response of marine bacterioplankton to differential filtration and confinement. Appl Environ Microbiol 47:49-55

Fuhrman JA, Noble RT (1995) Viruses and protists cause similar bacterial mortality in coastal seawater. Limnol Oceanogr 40:1236-1242 
Gasol JM, Del Giorgio PA, Duarte C (1997) Biomass distribution in marine planktonic communities. Limnol Oceanogr 42:1353-1363

Gonzàlez JM (1996) Efficient size-selective bacterivory by phagotrophic nanoflagellates in aquatic systems. Mar Biol $126: 785-789$

Hall JA, Barrett DP, James MR (1993) The importance of phytoflagellate, heterotrophic flagellate and ciliate grazing on bacteria and picophytoplankton sized prey in a coastal marine environment. J Plankton Res 15:1075-1086

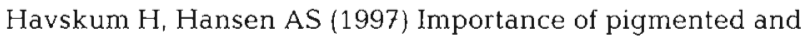
colourless nano-sized protists as grazers on nanoplankton in a phosphate-depleted Norwegian fjord and in enclosures. Aquat Microb Ecol 12:139-151

Havskum H, Riemann B (1996) Ecological importance of bacterivorous, pigmented flagellates (mixotrophs) in the Bay of Aarhus, Denmark. Mar Ecol Prog Ser 137: $251-263$

Ignatiades L. (1998) The productive and optical status of the oligotrophic waters of the southern Aegean Sea (Cretan Sea), Eastern Mediterranean. J Plankton Res 20: 985-995

Jürgens K, DeMott WR (1995) Behavioral flexibility in prey selection by bactivorous nanoflagellates. Limnol Oceanogr 40:1503-1507

Jürgens K, Güde H (1994) The potential importance of grazing-resistant bacteria in planktonic systems. Mar Ecol Prog Ser 112:169-188

Kana T, Glibert PM (1987) Effect of irradiances up to 2000 $\mu \mathrm{Em}^{-2} \mathrm{~s}^{-1}$ on marine Synechococcus WH 7803-1. Growth, pigmentation and cell composition. Deep-Sea Res 34: 479-516

Kirchman DL (1993) Leucine incorporation as a measure of biomass production by heterotrophic bacteria. In: Kemp PF, Sherr BF, Sherr EB, Cole JJ (eds) Handbook of methods in aquatic microbial ecology. Lewis Publishers, Ann Arbor, p 509-512

Kirchman DL, Newell SY, Hodson RE (1986) Incorporation. versus biosynthesis of leucine: implications for measuring rates of protein synthesis and biomass production by bacteria in marine systems. Mar Ecol Prog Ser 32:47-59

Krom DM, Kress N, Brenner S (1993) Nutrient distributions during an annual cycle across a warm-core eddy from the E. Mediterranean Sea. Deep-Sea Res 40:805-825

Landry MR, Lehner-Fourrier JM, Sundstrom JA, Fagerness VL, Selph KE (1991) Discrimination between living and heat-killed prey by a marine zooflagellate Paraphysomonas vestita Stokes. J Exp Mar Biol Ecol 146:139-15

Lee S, Fuhrman JA (1987) Relationships between biovolume and biomass of naturally derived marine bacterioplankton. Appl Environ Microbiol 53:1298-1303

Legrand C, Granéli E, Carlsson P (1998) Induced phagotrophy in the photosynthetic dinoflagellate Heterocapsa triquetra. Aquat Microb Ecol 15:65-75

Monger BC, Landry MR (1992) Size-selective grazing by heterotrophic nanoflagellates: an analysis using livestained bacteria and dual-beam flow cytometry. Arch Hydrobiol Beih Ergeb Limnol 37:173-185

Morita RY (1997) Bacteria in oligotrophic environments. Chapman \& Hall, New York

Editorial responsibility: Otto Kinne (Editor), Oldendorf/Luhe, Germany
Nygaard K, Tobiesen A (1993) Bacterivory in algae: a survival strategy during nutrient limitation. Limnol Oceanogr 38 $273-279$

Nygaard K, Børsheim KY, Thingstad TF (1988) Grazing rates on bacteria by marine heterotrophic microflagellates compared to uptake rates of bacterial-sized monodisperse fluorescent latex beads. Mar Ecol Prog Ser 44:159-16529

Pace ML, McManus GB, Findlay SEG (1990) Planktonic community structure determines the fate of bacterial production in a temperate lake. Limnol Oceanogr 35:795-808

Pollard PC, Moriarty D (1984) Validity of the tritiated thymidine method for estimating bacterial growth rates: measurement of isotope dilution during DNA synthesis. Appl Environ Microbiol 48:1076-1083

Porter KG, Feig YS (1980) The use of DAPI for identifying and counting aquatic microflora. Limnol Oceanogr 25: 943-948

Riemann B, Havskum H, Thingstad F, Bernard C (1995) The role of mixotrophy in pelagic environments. In: Joint I (ed) NATO ASI Series, Molecular ecology of aquatic microbes, Vol 38. Springer-Verlag, Berlin, p 87-114

Robarts RD, Zohary T, Waiser MJ, Yacobi YZ (1996) Bacterial abundance, biomass, and production in relation to phytoplankton biomass in the Levantine Basin of the southeastern Mediterranean Sea. Mar Ecol Prog Ser 137:273-281

Rothhaupt KO (1996) Utilization of substitutable carbon and phosphorus sources by the mixotrophic chrysophyte Ochromonas sp. Ecology 77:706-715

Sanders RW (1991) Mixotrophic protists in marine and freshwater ecosystems. J Protozool 38:76-81

Sherr BF, Sherr EB, Fallon RD (1987) Use of monodispersed fluorescently labelled bacteria to estimate in situ protozoan bacterivory. Appl Environ Microbiol 53:958-965

Simek K, Chrzanowski T (1992) Direct and indirect evidence of size-selective grazing on pelagic bacteria by freshwater nanoflagellates. Appl Environ Microbiol 58: $3715-3720$

Steward GF, Smith DC, Azam F (1996) Abundance and production of bacteria and viruses in the Bering and Chukchi Seas. Mar Ecol Prog Ser 131:287-300

Theil-Nielsen J, Sondergaard M (1998) Bacterial carbon biomass calculated from biovolumes. Arch Hydrobiol 141: $195-207$

Thingstad TF, Havskum H, Garde K, Riemann B (1996) On the strategy of 'eating your competitor'. A mathematical analysis of mixotrophy. Ecology 77:39-49

Thingstad TF, Zweifel UL, Rassoulzadegan F (1998) P limitation of heterotrophic bacteria and phytoplankton in the Northwest Mediterranean. Limnol Oceanogr 43: 88-94

Van Wambeke F, Christaki U, Bianchi M, Tselepides T, Psarra $S$ (in press) Heterotrophic bacterial production in the Cretan Sea. Prog Oceanogr

Zohary T, Robarts RD (1998) Experimental study of microbial $P$ limitation in the eastern Mediterranean. Limnol Oceanogr 43:387-395

Zubkov MV, Sleigh MA (1995) Bacterivory by starved marine heterotrophic nanoflagellates of two species which feed differently, estimated by uptake of dual radioactivelabelled bacteria. FEMS Microbiol Ecol 17: 57-65

Submitted: July 27, 1998; Accepted: November 26, 1998

Proofs received from author(s): April 22, 1999 